\title{
Editorial
}

\section{Violence against women in Pakistan - A cultural or a criminal problem?}

\author{
Laila Tul Qadarl, Osama Shabbir ${ }^{l}$ \& Fauzia Imtiaz ${ }^{2}$
}

${ }^{1}$ Dow University of Health Sciences, Karachi, Pakistan.

${ }^{2}$ Department of Biochemistry, Dow Medical College, Dow University of Health Sciences

Corresponding Author Email: lailarahman1997@ hotmail.com

There are various problems and issues surrounding the subject of violence against women but the most complex one is the harassment and violence against them. This has always been a dominating social and public health problem which always needs a considerable attention, as it depicts physical, psychological, social and emotional significances (Sarwar, 2013 \& Pico-Alfonso et al., 2006) According to World Health Organization (WHO), it is estimated that globally about 1 in $3(35 \%)$ of women worldwide suffers intimidation, domination, victimization and/or emotional abuse affected by the intimate sexual partner (World Health Organization, 2017). Interpreting violence against women is a complicated issue which includes beating, murder, kidnap, rape, physical assault, acid throwing, forcefully aborting female babies, battering and courtship violence (Khan et al., 2009)

In a conservative patriarchal nation like Pakistan it is not surprising that such attacks against women are on a rise. In 2013 reports by Human Rights Commission of Pakistan there were 2,576 cases of rape, 1000 cases of honor killings, 389 cases of domestic violence by male intimate partner, 150 acid attack cases and 56 murder cases just for giving birth to a female child (Women - Rights of the disadvantaged, 2015). Reports of 2014 statistics shows that 597 women and girls were gang raped and 36 were stripped naked publicly (Women Rights of the disadvantaged, 2015). In the span of one year (2015-2016) 11,000 females were killed by their family members who believed that she had disgraced the honor of the family. In this yearly report it was witnessed that 900 women suffered sexual violence and 800 women tried to commit suicide (Women - Rights of the disadvantaged, 2015).

Moreover, Pakistan faces high maternal mortality ratio prevalent in disease stricken impoverished areas not in access with basic health care, nutrition, and education, and law and order seems helpless (Khan et al., 2009). As, Speaking Out: Recalling Women's Aid in Scotland started their campaign with the sole purpose of raising voices of women (Speaking Out, 2018). This movement aid to victims of domestic abuse and has ran successful campaign for law amendments, funding and, in altering masses perception around domestic abuse topic. All the participating women formed groups, wrote compelling letters to the law makers, raised funds and condemned those published articles and court cases which were sympathetic towards male perpetrators of violence against women (Women Rights of the disadvantaged, 2015). Pakistan is also a patriarchal society in which women are forced to follow needless social, cultural, and religious norms set by their male counterparts, thus gravely hindering development of leadership skills and participation in the law and policymaking process (World Health Organization, 2017).

Such major incidence of violence against women clearly shows the apparent gap between the existing laws and their enforcement (Violence Against Women, 2018 \& Mitchell, 2017). This is due to the idle criminal justice system, lack of political will and feeble public pressure. Understanding the issue to its core is the only way the Pakistani government can work on it to make reforms. This can be achieved if investments like general awareness programs for all members for society are held by the electronic media, increasing education in poverty-stricken areas where illiteracy is high, platforms for women to voice their opinions and equal opportunities for everyone for their basic human rights including good salaries for female class for social up gradation. If such incentives are not taken, then the patriarchal living would continue to produce weak femininity in future, would lead to corrupt justice system and loss of precious lives.

\section{Conflict of Interest}

None.

\section{Acknowledgment}

We would like to express our great appreciation to Dr. Lubna Riaz for her constructive suggestions during the planning and development of this article. Her willingness to give her time so generously has been very much appreciated.

\section{Funding}

None.

\section{References}

- Khan, Y. P., Bhutta, S. Z., Munim, S., \& Bhutta, Z. A. (2009). Maternal health and survival in Pakistan: issues and options. J Obstet Gynaecol Can, 31(10), 920-929.

- Mitchell, F. (2017). Fighting for an end to violence against women. The Lancet, 389(10065), 146. 
- Pico-Alfonso, M. A., Garcia-Linares, M. I., Celda-Navarro, N., Blasco-Ros, C., Echeburúa, E., \& Martinez, M. (2006). The impact of physical, psychological, and sexual intimate male partner violence on women's mental health: depressive symptoms, posttraumatic stress disorder, state anxiety, and suicide. J. Womens Health, 15(5), 599-611.

- Sarwar, F., \& Abbasi, A. S. (2013). An in-depth analysis of women's labor force participation in Pakistan. Middle-East J. Sci. Res, 15(2), 208215.

- Speaking Out: Recalling Women's Aid in Scotland. (2018). Glasgow Women's Library. Retrieved from: https://womenslibrary.org.uk/discover-ourprojects/speaking-out/

- Violence Against Women. (2018). Cultural Anthropology, Chapter 10: Sex \& Gender, Retrieved from: https://courses.lumenlearning.com/culturalanthr opology/chapter/violence-against-women/

- Women - Rights of the disadvantaged. (2015). Retrieved from: http://hrcpweb.org/hrcpweb/wpcontent/uploads/2016/04/Women_12.pdf

- World Health Organization (WHO) (2017): Violence against women - Intimate partner sexual violence. Retrieved from: http://www.who.int/mediacentre/factsheets/fs 23 9/en/Factsheet 